\title{
Release Reductions of Gaseous Ammonia and Nitrogen Oxides from Electrochemical Treatment of Swine Wastewater
}

\author{
Kuo-Lin Huang ${ }^{*}$, Chou-Ching Liu ${ }^{1}$, Chia-Wei Lee ${ }^{2}$, Chen-Yao Ma ${ }^{3}$, Ting-Chun Lin ${ }^{4}$, \\ Jen-Hsiung Tsai ${ }^{1}$, Shui-Jen Chen ${ }^{1}$ \\ ${ }^{1}$ Department of Environmental Engineering and Science, National Pingtung University of Science and Technology, \\ Pingtung 91201, Taiwan \\ ${ }^{2}$ Department of Safety, Health and Environmental Engineering, National Kaohsiung University of Science and \\ Technology, Kaohsiung 824, Taiwan \\ ${ }^{3}$ Environmental Protection Bureau, Kaohsiung City Government, Kaohsiung 83347, Taiwan \\ ${ }^{4}$ Prosperity Sci-Tech Co., Ltd., Taipei 10067, Taiwan
}

\begin{abstract}
This study investigates the release of $\mathrm{NH}_{3}$ and nitrogen oxides $\left(\mathrm{NO}_{x}\right)$ from wastewater into the air in relation to the variations in $\mathrm{NH}_{3}-\mathrm{N}, \mathrm{NO}_{2}{ }^{-} \mathrm{N}, \mathrm{NO}_{3}{ }^{-} \mathrm{N}$, and chemical oxygen demand (COD) concentrations in the swine wastewater with/without electrolysis using boron-doped diamond (BDD), $\mathrm{PbO}_{2}$, and graphite anodes. The $\mathrm{NH}_{3}$ concentration in the air right above the swine wastewater without electrolysis increased over time and this increase was greater when the wastewater $\mathrm{NH}_{3}-\mathrm{N}$ concentration was higher. Electrolysis could reduce the release of $\mathrm{NH}_{3}$ from swine wastewater into the air. The $\mathrm{NO}$ concentration in the air was greater for the wastewater without electrolysis than for that with electrolysis but an opposite trend was observed for $\mathrm{NO}_{2}$, although the corresponding $\mathrm{NO}_{\mathrm{x}}$ concentrations for the wastewater with and without electrolysis were similar. Roughly, the air $\mathrm{NH}_{3}, \mathrm{NO}, \mathrm{NO}_{2}$, or $\mathrm{NO}_{\mathrm{x}}$ concentrations for using the different anodes in wastewater electrolysis followed the order $\mathrm{Nb} / \mathrm{BDD}>>$ graphite/BDD $>$ graphite $>$ graphite $/ \mathrm{PbO}_{2} \approx \mathrm{Ti} / \mathrm{PbO}_{2}$. Although the $\mathrm{BDD}$ and graphite anodes showed less formation of nitrite or nitrate than the $\mathrm{PbO}_{2}$ anodes, the graphite/BDD and graphite anodes had worse performance in $\mathrm{NH}_{3}-\mathrm{N}$ or COD electro-degradation than the other tested ones. When the initial concentration of $\mathrm{NH}_{3}-\mathrm{N}_{\text {or }}$ COD was higher, its specific energy consumption in electrolysis was lower.
\end{abstract}

Keywords: Swine wastewater; Electrochemical degradation; Anode material; Ammonia reduction; Nitrogen oxides.

\section{INTRODUCTION}

Pig farming including intensive or large-scale raising and breeding operations is still necessary to meet the increasing pork demand in several countries (Osada et al., 2017; Song et al., 2017). Despite the recent spread of African swine fever to new areas or countries, China, the United States and the European Union held the first, second, and third positions, respectively, for the global pork production in 2018 (Deblitz et al., 2018). This phenomenon causes the generation of considerable amounts of swine wastewater which needs to be well treated before discharge for the prevention of surface and underground water pollution, because several types of pollutants including high levels of organic and nitrogen compounds might be present in swine wastewater, which are

\footnotetext{
* Corresponding author.

Tel.: +886-8-7703202 ext. 7092; Fax: +886-8-7740256

E-mail address: huangkL@mail.npust.edu.tw
}

regulated by water quality parameter limits (U.S. EPA, 2013; Ding et al., 2017; Osada et al., 2017; Song et al., 2017).

Another great environmental concern for pig farming is the emissions of ammonia $\left(\mathrm{NH}_{3}\right)$ and greenhouse gases (e.g., $\mathrm{CH}_{4}, \mathrm{CO}_{2}$, and $\mathrm{N}_{2} \mathrm{O}$ ) from the wastewater in purification facilities or the slurry in storages at pig farms prior to land application (Viguria et al., 2015; Osada et al., 2017). According to the European Environment Agency (EEA, 2019), ammonia and nitrogen oxides $\left(\mathrm{NO}_{\mathrm{x}}\right)$ are two of four key air pollutants with emissions restricted by the EU legislation from 2010 onward, and emissions of ammonia from the agricultural sector continue to rise, posing a challenge for EU Member States in meeting EU air pollution limits. Guthrie et al. (2018) also indicates that the agricultural sector is the biggest contributor to ammonia pollution in the UK. Although the levels of other air pollutants have declined, ammonia is one of the main sources of nitrogen pollution, alongside nitrogen oxides, and ammonia emissions have been rising since 2013 in the UK, with significant implications for biodiversity and human health. $\mathrm{NH}_{3}$ and $\mathrm{NO}_{\mathrm{x}}$ are two of most important pollutants that need more intensive monitoring for the air 
pollution at Kathmandu Valley in Nepal (Kiros et al., 2016). These compounds are also two of N-containing acidifying pollutants which may deposit from the atmosphere to the ground (Wright et al., 2018) and impacts species composition through soil acidification (Guthrie et al., 2018). In addition to agricultural sources, $\mathrm{NH}_{3}$ (reduced $\mathrm{N}$ ) may also be produced from biomass burning, while $\mathrm{NO}_{\mathrm{x}}$ (oxidized $\mathrm{N}$ ) can be contributed from different sources, such as vehicle emissions, industry, and domestic combustion, and electricity generation (Wright et al., 2018). $\mathrm{NH}_{3}$ and $\mathrm{NO}_{\mathrm{x}}$ are regarded as precursor gases which may influence the chemical compositions of $\mathrm{PM}_{2.5}$, visibility, and air quality (Li et al., 2018), so they are concerned for their spatio-temporal variations (Cai et al., 2018; Cheng et al., 2018) and long-range transport (Sadanaga et al., 2017).

Ammonia and hydrogen sulfide are the main odor gases related to manure swine houses (usually causing a nuisance for surrounding communities), although odor from inside swine production facilities is a complex mixture of gases ( $\sim 330$ different compounds), primarily due to manure decomposition under anaerobic conditions (Rahman and Borhan, 2012; Ubeda et al., 2013). Therefore, manure treatment systems are necessary for controlling the ammonia and odor emission from swine wastewater. Odor emission from liquid manure can be reduced by a three-step process: solid-liquid separation of manure, anaerobic digestion, and aerobic biological treatment (for the removal of organic and nitrogen compounds) (Rahman and Borhan, 2012; Montes et al., 2015). This process is also adopted in Taiwan for swine wastewater treatment; however, it has the disadvantages of time-consuming, low ammonia removal, and poor odor control. Moreover, ammonia is one of air toxic pollutants regulated by Air Pollution Control Act Enforcement Rules in Taiwan.

Electrochemical advanced oxidation process (EAOP) is a more efficient approach than the three-step one for swine wastewater treatment to alleviate the swine wastewater pollution along with its odor nuisance including ammonia emission. Generated in EAOP, hydroxyl radical $(\cdot \mathrm{OH})$ is a powerful oxidant which is highly reactive for degrading organic pollutants in wastewater. In the presence of chloride, active chlorine can be electrochemically generated in the EAOP and it is very efficient for removing ammonia and other nitrogen-containing compounds in wastewater $(\mathrm{Li}$ and Liu, 2009; Sirés et al., 2014; Radjenovic et al., 2015; Moreira et al., 2017). For this purpose and the effective production of $\bullet \mathrm{OH}$ for chemical oxygen demand (COD) degradation, EAOP highly relies on the use of non-active anode materials (e.g., $\mathrm{PbO}_{2}$ and boron-doped diamond [BDD]) (Li and Liu, 2009; Sirés et al., 2014; Radjenovic et al., 2015; Moreira et al., 2017). In our previous work, we explored the removal of $\mathrm{COD}$ and ammonia in swine wastewater at different operating parameters (Huang et al., 2018, 2019). However, little attention has been paid to release of $\mathrm{NH}_{3}$ and nitrogen oxides $\left(\mathrm{NO}_{\mathrm{x}}\right)$ from wastewater into the air in association with the variations in $\mathrm{NH}_{3}-\mathrm{N}, \mathrm{NO}_{2}^{-}-\mathrm{N}, \mathrm{NO}_{3}{ }^{-}-\mathrm{N}$, and $\mathrm{COD}$ concentrations in the swine wastewater with/without electrolysis. Therefore, this study focuses on the investigation of gaseous ammonia and nitrogen oxides emitted from electrochemical treatment of swine wastewater using different anode materials.

\section{MATERIALS AND METHODS}

\section{Electrolysis of Swine Wastewater}

The electrolysis of swine wastewater with the addition of $0.05 \mathrm{M} \mathrm{NaCl}$ was performed in an undivided electrochemical cell at room temperature $\left(25^{\circ} \mathrm{C}\right)$ and $0.25 \mathrm{~A} \mathrm{~cm}^{-2}$ (Fig. 1). A Ti plate was used as the cathode, while the anode material was BDD-I (Nb/BDD from Neocoat, Germany), lab-prepared substance $\left(\mathrm{Ti} / \mathrm{PbO}_{2}\right.$, graphite $/ \mathrm{PbO}_{2}$, or graphite/BDD), or graphite. The fabrication method for the lab-prepared $\mathrm{PbO}_{2}$ was provided elsewhere (Chen et al., 2012), whereas the fabrication of graphite/BDD referred to an approach of hot filament chemical vapor deposition (HFCVD) (Pinheiro et al., 2012). A DC power supply (Twintex TP2H-20S, Taiwan,) was used to monitor the cell voltage and current over time in the electrolytic experiments.

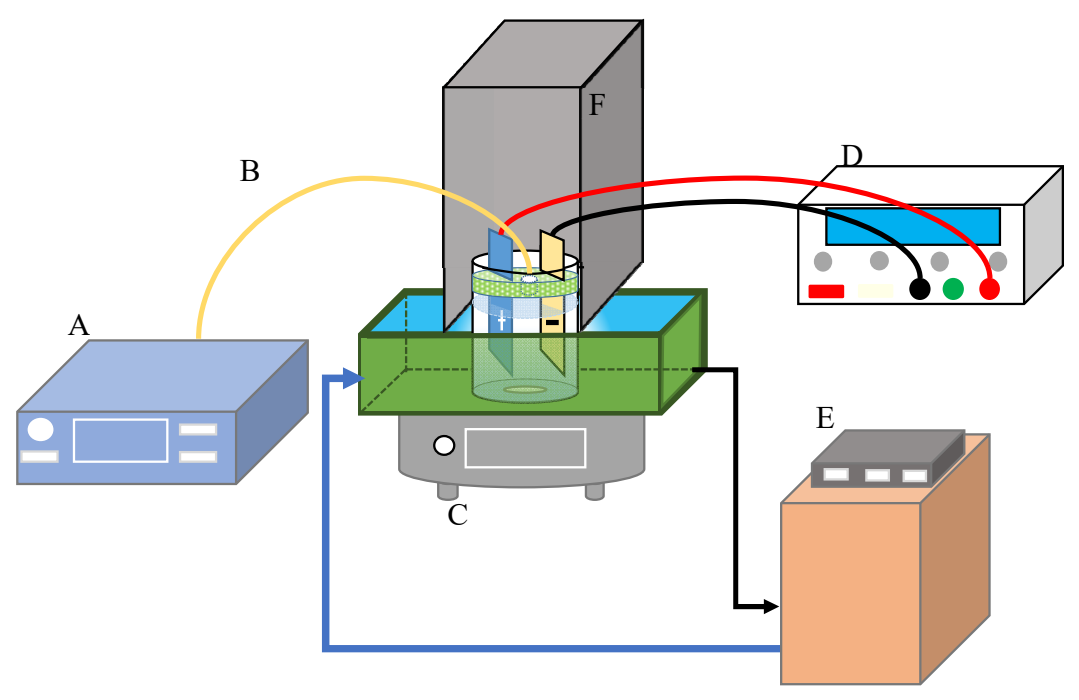

Fig. 1. The scheme of experimental device (A: Ammonia analyzer, B: Sampling tube, C: Magnetic stirrer, D: DC power supply, E: thermostatic bath, F: Three-side rectangular box, +: Anode, and -: Cathode). 
The degradation or removal efficiency of $\mathrm{COD}$ or $\mathrm{NH}_{3}-\mathrm{N}$ was calculated using the following equation:

Degradation or removal efficiency $=\left(1-\mathrm{C}_{\mathrm{t}} / \mathrm{C}_{0}\right) \times 100 \%$

where $\mathrm{C}_{t}$ is the residual concentration of either $\mathrm{COD}$ or $\mathrm{NH}_{3}-\mathrm{N}$ at a given electrolysis time $t$ and $\mathrm{C}_{0}$ is the initial concentration of COD or $\mathrm{NH}_{3}-\mathrm{N}$.

The specific energy consumption $\left(\mathrm{E}_{\mathrm{SP}}\right)\left(\mathrm{kWh} \mathrm{g}-\mathrm{COD}^{-1}\right.$ or $\mathrm{kWh}$ g- $\left.\mathrm{NH}_{3}-\mathrm{N}^{-1}\right)$ was determined using the following calculation (Martínez-Huitle and Ferro, 2006; Radjenovic et al., 2015):

$\mathrm{E}_{\mathrm{SP}}=\mathrm{E}_{\mathrm{cv}} \mathrm{It} /\left(\mathrm{C}_{0}-\mathrm{C}_{\mathrm{t}}\right) \mathrm{V}_{\mathrm{wv}}$

where $E_{c v}$ is the average cell voltage $(\mathrm{V})$; I is the applied current $(\mathrm{A}) ; \mathrm{V}_{\mathrm{wv}}$ is the wastewater volume (L).

\section{Analysis of Ammonia and Nitrogen Oxides in the Air}

An ammonia analyzer (Ecoech Serinus-44) was used to directly collect air samples and quantify the concentrations of $\mathrm{NH}_{3}, \mathrm{NO}, \mathrm{NO}_{2}$, and $\mathrm{NO}_{\mathrm{x}}$ in the air right above the electrolytic cell holding swine wastewater with or without electrolysis (Fig. 1). In experiments, the swine wastewater was well mixed using a magnetic stirrer (stir bar, length $=4$ $\mathrm{cm}$ and diameter $=0.8 \mathrm{~cm}$ ) operated at $320 \mathrm{rpm}$, which proceeded the thorough mixing of swine wastewater without vortex formation in the electrochemical reactor (diameter $=$ $6 \mathrm{~cm}$ ). The air entrance of sampling tube was placed at $4 \mathrm{~cm}$ right above the swine wastewater and the sampling space was three-side surrounded by a paper holder to reduce interference of air flow and provide temporary accumulation of species of interest for sampling. The method detection limits of these nitrogen compounds are all $0.4 \mathrm{ppb}$, while their upper limits of quantitation are the same (20 ppm). The reported concentrations of these four species in the air were all background (blank) corrected. These data were obtained in laboratories $\mathrm{A}$ and $\mathrm{B}$, and the former had higher background air ammonia concentrations than the latter ( 100 ppb).

\section{Chemical Analysis of Swine Wastewater}

The swine wastewater samples, obtained from two pig farms in southern Taiwan, were stored at $4{ }^{\circ} \mathrm{C}$ before use. Prior to testing, each sample was filtered using a $0.45 \mu \mathrm{m}$ filter to remove suspend solids. The methods set forth in the National Institute of Environmental Analysis (NIEA) (Taiwan) W517.52B, W203.51B, W448.51B, W418.53C, $\mathrm{W} 419.51 \mathrm{~B}$, and $\mathrm{W} 424.52 \mathrm{~A}$ were used for the analyses of COD, conductivity (EC), ammonium nitrogen $\left(\mathrm{NH}_{3}-\mathrm{N}\right)$, nitrite nitrogen $\left(\mathrm{NO}_{2}^{-}-\mathrm{N}\right)$, nitrate nitrogen $\left(\mathrm{NO}_{3}^{-}-\mathrm{N}\right)$, and $\mathrm{pH}$ respectively.

A COD analyzer (COD Reactor CR25, Rocker) coupled with a colorimeter (Hach-DR900) was used to analyze the COD concentrations of samples. The required digestion for the ammonia measurements was conducted by a Gerhardt VAP-200 Kjeldahl Nitrogen Distillation System. The $\mathrm{NH}_{3}-\mathrm{N}$ in wastewater was spectrophotometrically measured at 640 nm (Hanna HI 96715) based on the reaction of ammonia with phenol and hypochlorite catalyzed with nitroprusside to form intensively blue indophenol in an alkaline medium (Berthelot reaction). Some ammonia measurements were also performed using a Hach-DR900 analyzer.

Sulfanilamide was used to diazotize the nitrite nitrogen of a sample followed by coupling with N-(1-naphthyl)ethylenediamine dihydrochloride (NED), and the concentration of nitrite was then photometrically analyzed at $543 \mathrm{~nm}$. Nitrate was also spectrophotometrically determined at $220 \mathrm{~nm}$ through deduction of the double absorbance at $275 \mathrm{~nm}$ for each sample. The chloride concentration was quantitatively determined using a redox potential titrator (Metrohm 702 $\mathrm{SM}$ Titrino), while the EC and $\mathrm{pH}$ were measured using an SC-170 conductivity meter (Suntex, Taiwan) and a TS-100 $\mathrm{pH}$ meter, respectively.

\section{RESULTS AND DISCUSSION}

\section{Concentrations of $\mathrm{NH}_{3}$ in the Air and $\mathrm{NH}_{3}-\mathrm{N}$ in the Wastewater without Electrolysis}

The air $\mathrm{NH}_{3}$ samples were collected in two laboratories (A and $\mathrm{B}$ ), so the background $\mathrm{NH}_{3}$ concentrations in the air in the laboratories need to be measured before the tests of swine wastewater. In fact, the background $\mathrm{NH}_{3}$ concentrations in the air in the laboratories varied with time. Figs. 2(a)-2(b) show two examples of the time-dependent concentration profiles of background air $\mathrm{NH}_{3}$ collected in laboratory A. The air $\mathrm{NH}_{3}$ concentrations fluctuated within the range of 262-404 ppb for a minute-based measurement (Fig. 2(a)), while those for an hour-based measurement ranged from $86-$ $754 \mathrm{ppb}$ (Fig. 2(b)). The latter had an increase in air $\mathrm{NH}_{3}$ concentration during daytime, mainly due to the increase in worker activity during office hours in the laboratory, because the chemical composition of human perspiration includes urea and the ammonia nitrogen can be detected in human perspiration (Thurmon and Ottenstein, 1952).

Figs. 3(a)-3(b) show the variation air $\mathrm{NH}_{3}$ concentrations along with that of wastewater $\mathrm{NH}_{3}-\mathrm{N}$ over time at similar initial wastewater $\mathrm{NH}_{3}-\mathrm{N}$ concentrations (99.5 and $97.2 \mathrm{mg} \mathrm{L}^{-1}$, respectively) in laboratory $\mathrm{A}$. As can be seen from these two figures, the $\mathrm{NH}_{3}$ concentrations in the air right above the electrolytic cell without operation were significantly higher that of background air. This phenomenon is associated with the release of $\mathrm{NH}_{3}$ from the swine wastewater into the air, because ammonia is a volatile compound which may partition itself between the liquid and the gas above the liquid (Arogo et al., 1999). According to Arogo et al. (1999), the mass transfer rate of $\mathrm{NH}_{3}$ from the swine wastewater into the air is proportional to the product of a mass transfer rate constant, the interfacial surface area, and a concentration driving force:

$$
\frac{d m}{d t}=k A_{s}\left(C_{w}-C_{\text {air }}\right)
$$

where $\mathrm{m}$ is the mass of ammonia, $\mathrm{k}$ is the overall mass transfer coefficient of ammonia, $A_{s}$ is the interfacial surface area, $C_{w}$ is the ammonia concentration in wastewater, $C_{a i r}$ is the ammonia concentration in the air, and $t$ is time. 

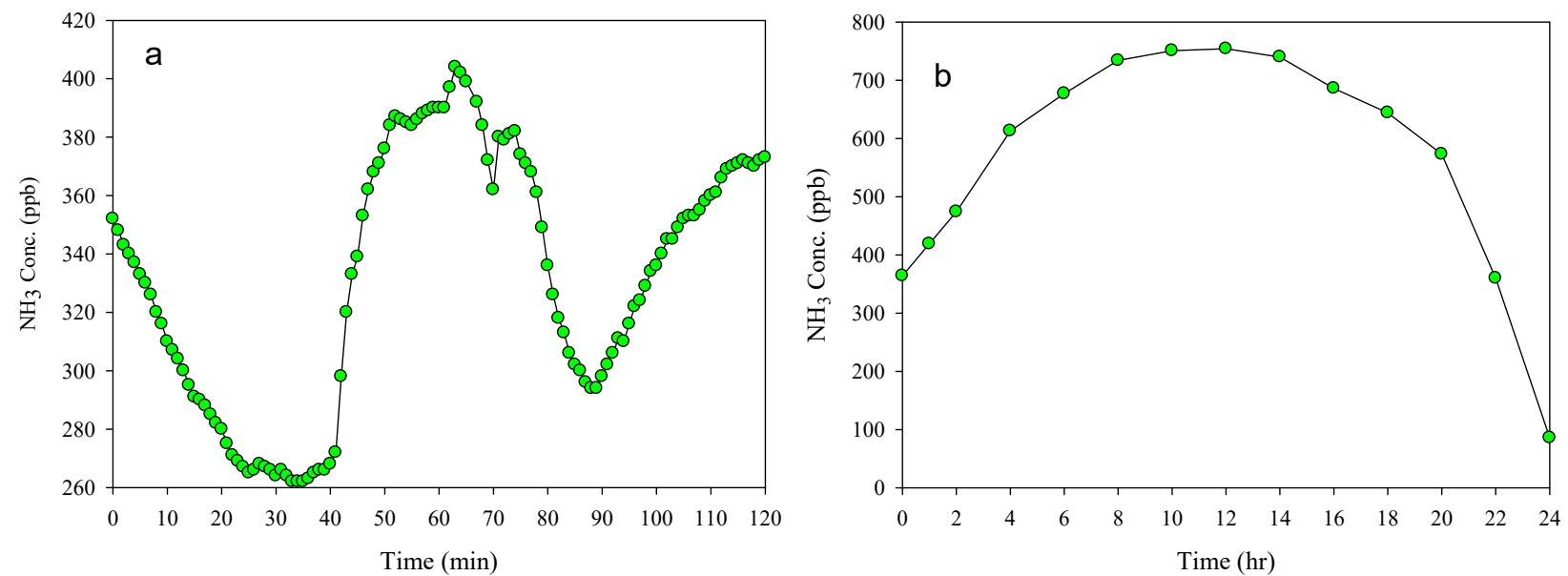

Fig. 2. Air $\mathrm{NH}_{3}$ concentration variations over time ((a) 2 and (b) $24 \mathrm{hrs)}$ in laboratory A.
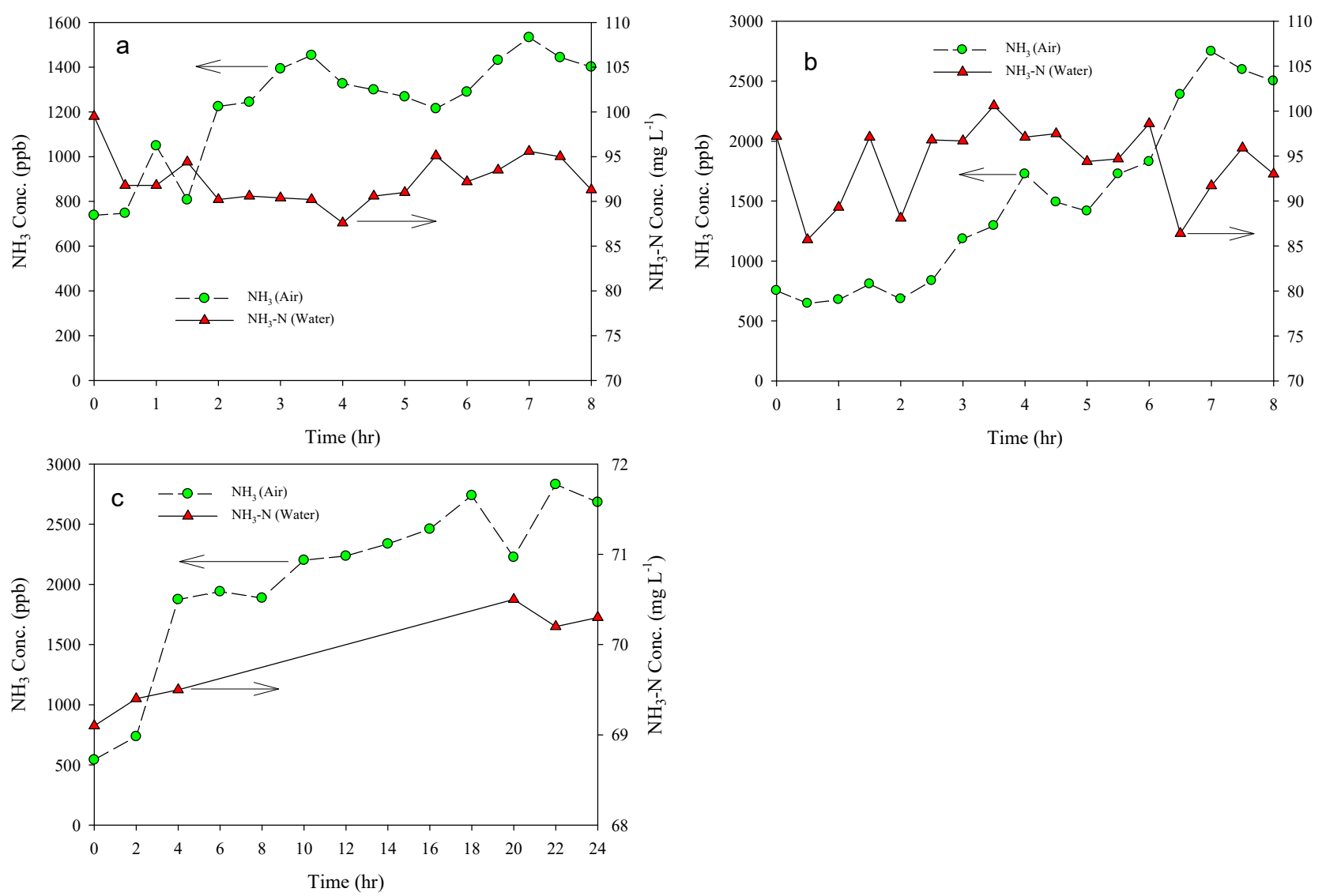

Fig. 3. Air $\mathrm{NH}_{3}$ and wastewater $\mathrm{NH}_{3}-\mathrm{N}$ concentration variations over time at different initial wastewater $\mathrm{NH}_{3}-\mathrm{N}$ concentrations or sampling durations ((a) 99.5 (8-hr), (b) 97.2 (8-hr), and (c) 69.1 (24-hr) mg L ${ }^{-1}$ ) (laboratory A).

Moreover, the ammonia volatilization might be influenced by other factors such as air velocity, air temperature, liquid temperature, and system geometry. Although the fluctuation of $\mathrm{NH}_{3}-\mathrm{N}$ concentrations in the swine wastewater was observed, it was almost negligible in comparison to that of $\mathrm{NH}_{3}$ concentrations in the air. This trend was also found when increasing the hourly sampling from 8 to $24 \mathrm{hrs}$ for the wastewater with a lower initial $\mathrm{NH}_{3}-\mathrm{N}$ concentration (Fig. 3(c)). The gradual rise of ammonia concentration in the air above the swine wastewater with the increase of time is attributed to the continuing release of ammonia with an increasing time and its temporary accumulation in the sampling space.

Variations of $\mathrm{NH}_{3}$ and Nitrogen Oxides Concentrations in the Air and of $\mathrm{NH}_{3}-\mathrm{N}$ in the Wastewater with/without Electrolysis

Increasing over time like the trend shown in Figs. 3(a)-3(b), 
the air $\mathrm{NH}_{3}$ concentrations (2186-12858 ppb) in Fig. 4(a) were significantly higher than those in Figs. 3(a)-3(b), because the swine wastewater (stirring [S] only) had a significantly higher initial $\mathrm{NH}_{3}-\mathrm{N}$ concentration $\left(661 \mathrm{mg} \mathrm{L}^{-1}\right)$. During the electrolysis $(\mathrm{E})$ of this swine wastewater $(\mathrm{S}+\mathrm{E})$, the air $\mathrm{NH}_{3}$ concentrations, also increasing over time at $\mathrm{t} \leq 150 \mathrm{~min}$, were significantly smaller (738-4985 ppb) than those without electrolysis; additionally, the decrease in air $\mathrm{NH}_{3}$ concentration was observed at $\mathrm{t}>150 \mathrm{~min}$. This result is attributed to the decrease in driving force for ammonia volatilization (Eq. (3)) because of the decrease in wastewater $\mathrm{NH}_{3}-\mathrm{N}$ concentration (from $661 \mathrm{mg} \mathrm{L}^{-1}$ at $\mathrm{t}=0$ min to $<0.01 \mathrm{mg} \mathrm{L}^{-1}$ at $\mathrm{t}=240 \mathrm{~min}$ ) (pseudo first order rate constant of $\mathrm{NH}_{3}-\mathrm{N}$ removal $\mathrm{k}_{\mathrm{NH} 3-\mathrm{N}}=$ $\left.1.33 \times 10^{-4} \mathrm{~s}^{-1}\right)($ Table 1$)$.
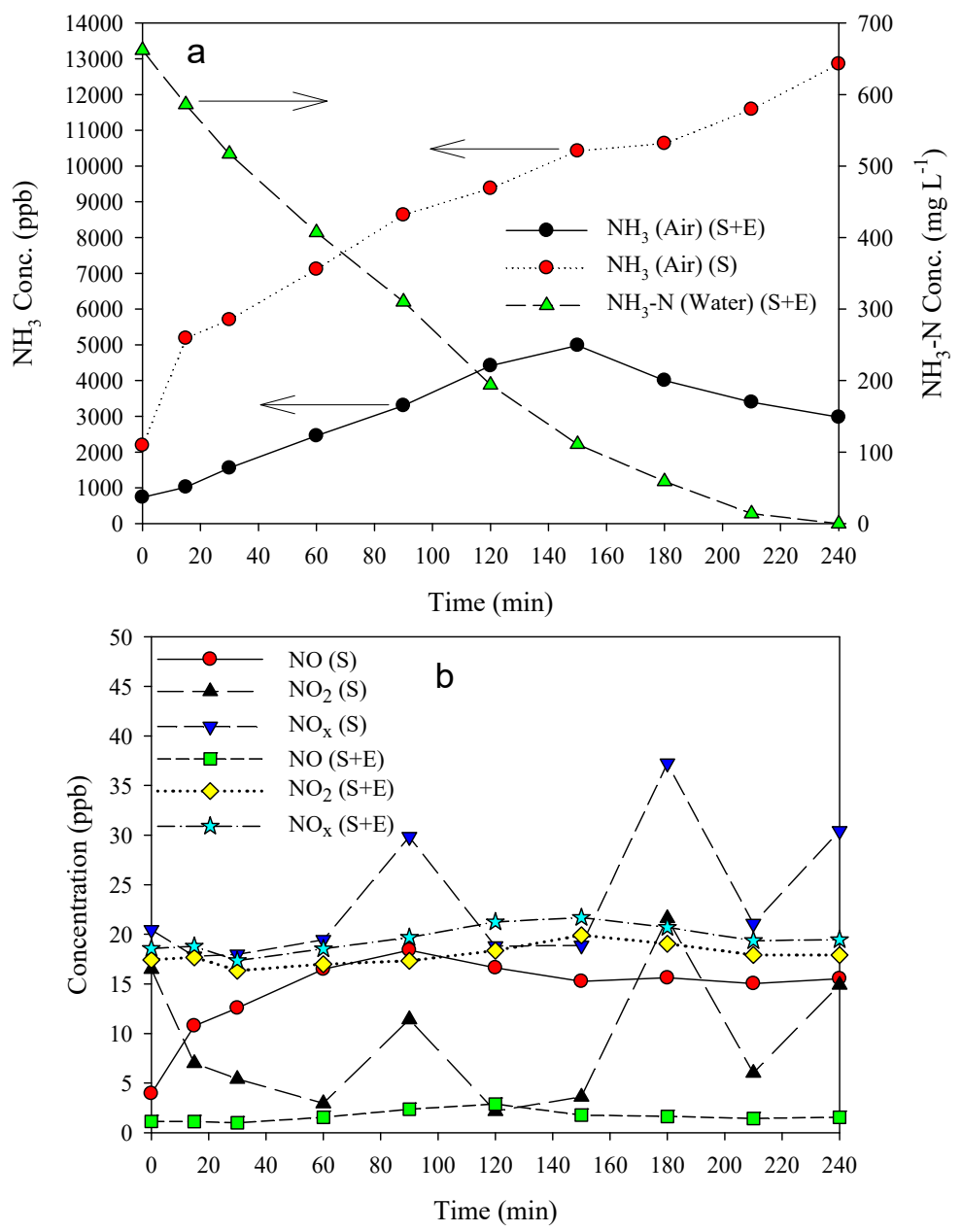

Fig. 4. (a) Air $\mathrm{NH}_{3}$ and wastewater $\mathrm{NH}_{3}-\mathrm{N}$ concentration variations and (b) air nitrogen oxides $\left(\mathrm{NO}, \mathrm{NO}_{2}\right.$, and $\left.\mathrm{NO}_{\mathrm{x}}\right)$ concentration variations over time (E: electrolysis and S: stirring for wastewater) (laboratory B).

Table 1. Initial concentrations $\left(\mathrm{mg} \mathrm{L}^{-1}\right)$ of $\mathrm{COD}, \mathrm{NH}_{3}-\mathrm{N}, \mathrm{NO}_{2}{ }^{-}-\mathrm{N}$, and $\mathrm{NO}_{3}{ }^{-}-\mathrm{N}$ of tested wastewater (volume $=200 \mathrm{~mL}$ ); pseudo first order rate constants $\left(\mathrm{s}^{-1}\right)$ of $\mathrm{COD}$ and $\mathrm{NH}_{3}-\mathrm{N}$ removal $\left(\mathrm{k}_{\mathrm{COD}}\right.$ and $\mathrm{k}_{\mathrm{NH} 3-\mathrm{N}}$, respectively); specific energy consumptions of COD degradation (2-hr E $\mathrm{SP}_{-\mathrm{C}}, \mathrm{kWh}$ g-COD $\left.{ }^{-1}\right)$ and $\mathrm{NH}_{3}-\mathrm{N}$ removal $\left(0.5-\mathrm{hr} \mathrm{E}_{\mathrm{SP}-\mathrm{N}}, \mathrm{kWh} \mathrm{g}-\mathrm{NH}_{3}-\mathrm{N}^{-1}\right)$; and $\Delta \mathrm{N}_{\mathrm{T}}$ (2-hr, mg) (G: graphite and NA: not available).

\begin{tabular}{lllllllllll}
\hline Batch & Electrode & $\mathrm{COD}$ & $\mathrm{NH}_{3}-\mathrm{N}$ & $\mathrm{NO}_{2}^{-}-\mathrm{N}$ & $\mathrm{NO}_{3}^{-}-\mathrm{N}$ & $\mathrm{k}_{\mathrm{COD}}$ & $\mathrm{k}_{\mathrm{NH} 3-\mathrm{N}}$ & $\mathrm{E}_{\mathrm{SP}-\mathrm{C}}$ & $\mathrm{E}_{\mathrm{SP}-\mathrm{N}}$ & $\Delta \mathrm{N}_{\mathrm{T}}$ \\
\hline $\mathrm{I}$ & $\mathrm{BDD}-\mathrm{I}$ & 6266 & 661 & 1.58 & 88.5 & $1.21 \times 10^{-4}$ & $1.33 \times 10^{-4}$ & 0.052 & 0.316 & 89.8 \\
$\mathrm{II}-01$ & $\mathrm{Ti} / \mathrm{PbO} 2$ & $\mathrm{NA}$ & 98.2 & $\mathrm{NA}$ & $\mathrm{NA}$ & $\mathrm{NA}$ & $4.63 \times 10^{-4}$ & $\mathrm{NA}$ & 1.250 & 17.4 \\
$\mathrm{II}-02$ & $\mathrm{BDD}_{2}$ & $\mathrm{NA}$ & 82.0 & $\mathrm{NA}$ & $\mathrm{NA}$ & $\mathrm{NA}$ & $4.83 \times 10^{-4}$ & $\mathrm{NA}$ & 0.899 & 16.0 \\
$\mathrm{II}-1$ & $\mathrm{BDD}_{-\mathrm{I}}$ & 542 & 76.3 & 0.26 & 0.57 & $5.13 \times 10^{-4}$ & $5.13 \times 10^{-4}$ & 0.408 & 1.043 & 12.5 \\
$\mathrm{II}-2$ & $\mathrm{Ti}^{-} \mathrm{PbO}_{2}$ & 360 & 87.0 & 0.48 & 5.50 & $9.90 \times 10^{-4}$ & $5.38 \times 10^{-4}$ & 0.805 & 0.825 & 16.3 \\
$\mathrm{II}-3$ & $\mathrm{G} / \mathrm{PbO}_{2}$ & 480 & 82.1 & 0.80 & 2.63 & $1.19 \times 10^{-3}$ & $6.35 \times 10^{-4}$ & 0.658 & 0.963 & 14.4 \\
$\mathrm{II}-4$ & $\mathrm{G}$ & 484 & 90.0 & 0.32 & 5.96 & $4.50 \times 10^{-5}$ & $2.98 \times 10^{-4}$ & 0.593 & 6.703 & 10.1 \\
$\mathrm{II}-5$ & $\mathrm{G} / \mathrm{BDD}$ & 388 & 84.0 & 0.15 & 5.96 & $1.55 \times 10^{-4}$ & $3.68 \times 10^{-4}$ & 0.853 & 5.174 & 9.97 \\
\hline
\end{tabular}

Batch I: initial conductivity $=12.45 \mathrm{~ms} \mathrm{~cm}^{-1}, \mathrm{Cl}^{-}=1737 \mathrm{mg} \mathrm{L}^{-1}$, and $\mathrm{pH}=7.86$.

Batch II: initial conductivity $=7.40 \mathrm{~ms} \mathrm{~cm}^{-1}, \mathrm{Cl}^{-}=1895 \mathrm{mg} \mathrm{L}^{-1}$, and $\mathrm{pH}=7.34-7.80$. 
It is interesting to note that the NO concentration in the air was greater for the wastewater without electrolysis than for that with electrolysis, but an opposite tendency was observed for $\mathrm{NO}_{2}$ in the air (Fig. 4(b)). However, their corresponding $\mathrm{NO}_{\mathrm{x}}$ concentrations were similar at most of sampling intervals, although the NO concentrations were significantly higher at $\mathrm{t}=90,180$, and $240 \mathrm{~min}$ for the wastewater with electrolysis than for that without electrolysis. This finding is related to the conversion of ammonia into other nitrogen compounds. Without electrolysis, it is known that two groups of bacteria, Nitrosomonas and Nitrobacter may cause the oxic conversion of ammonia to nitrite and nitrate, respectively. However, ammonia oxidizers are able to oxidize ammonia under anoxic conditions (Schmidt and Bock, 1997). According to Stuven and Bock (2001), significant $\mathrm{NO}$ and $\mathrm{NO}_{2}$ production was observed during biological $\mathrm{N}$-elimination from synthetic wastewater and sludge liquor from the municipal wastewater treatment plant wastewater with high ammonium concentration (about $700 \mathrm{mg} \mathrm{N} \mathrm{L}^{-1}$ ); moreover, Nitrosomonas was an efficient $\mathrm{NO}$ producer and significant $\mathrm{NO}_{2}$ formed during simultaneous nitrification/denitrification. Nevertheless, various disinfecting oxidants such as chlorine, ozone, and hydroxyl radicals can be generated at BDD electrodes in $\mathrm{NaCl}$ solution (Yano et al., 1998). The free chlorine, active chlorine, or chloramines might involve in the inactivation of Nitrosomonas (europaea) (Chauret et al., 1998), which affected the production of $\mathrm{NO}$ and $\mathrm{NO}_{2}$ from nitrification in the wastewater and thus the release of nitrogen oxides from wastewater into the air, leading to the variations of nitrogen oxides in the air.

During the electrolysis of swine wastewater containing $0.05 \mathrm{M} \mathrm{NaCl}$ in this study, the electrochemical production of active chlorine $\left(\mathrm{Cl}_{2}, \mathrm{HOCl}\right.$, and $\left.\mathrm{OCl}^{-}\right)$could be achieved through the following two reactions (Kapałka et al., 2010).

$$
\begin{aligned}
& 2 \mathrm{Cl}^{-} \rightarrow \mathrm{Cl}_{2}+2 \mathrm{e}^{-} \\
& \mathrm{Cl}_{2}+\mathrm{H}_{2} \mathrm{O} \rightarrow \mathrm{HClO}+\mathrm{H}^{+}+\mathrm{Cl}^{-}
\end{aligned}
$$

Based on reactions 6-9, the $\mathrm{HOCl}$ from the above reaction could oxidize $\mathrm{NH}_{3}$ or $\mathrm{NH}_{4}{ }^{+}$to produce nitrogen gas or nitrate (Li and Liu, 2009).

$$
\begin{aligned}
& 3 \mathrm{HOCl}+2 \mathrm{NH}_{3} \rightarrow \mathrm{N}_{2}+3 \mathrm{H}_{2} \mathrm{O}+3 \mathrm{H}^{+}+3 \mathrm{Cl}^{-} \\
& 3 \mathrm{HOCl}+2 \mathrm{NH}_{4}^{+} \rightarrow \mathrm{N}_{2}+3 \mathrm{H}_{2} \mathrm{O}+5 \mathrm{H}^{+}+3 \mathrm{Cl}^{-} \\
& 4 \mathrm{HOCl}+\mathrm{NH}_{4}^{+} \rightarrow \mathrm{NO}_{3}{ }^{-}+\mathrm{H}_{2} \mathrm{O}+6 \mathrm{H}^{+}+4 \mathrm{Cl}^{-} \\
& 4 \mathrm{OCl}^{-}+\mathrm{NH}_{3} \rightarrow \mathrm{NO}_{3}{ }^{-}+\mathrm{H}_{2} \mathrm{O}+\mathrm{H}^{+}+4 \mathrm{Cl}^{-}
\end{aligned}
$$

Or $\mathrm{HOCl}$ might react with $\mathrm{NH}_{3}$ to form chloramines via reactions 10-12 (Kapałka et al., 2010; Pérez et al., 2012), while the formation of chloramines was indicated to be insignificant at $\mathrm{pH}>8$ (Pérez et al., 2012).

$$
\begin{aligned}
& \mathrm{HOCl}+\mathrm{NH}_{3} \rightarrow \mathrm{NH}_{2} \mathrm{Cl}+\mathrm{H}_{2} \mathrm{O} \\
& \mathrm{NH}_{2} \mathrm{Cl}+\mathrm{HOCl} \rightarrow \mathrm{NHCl}_{2}+\mathrm{H}_{2} \mathrm{O}
\end{aligned}
$$

$\mathrm{NHCl}_{2}+\mathrm{HOCl} \rightarrow \mathrm{NCl}_{3}+\mathrm{H}_{2} \mathrm{O}$

It was reported that ammonia can be electrochemically oxidized through several complicated steps to various nitrogen compounds such as $\mathrm{N}_{2}$ and $\mathrm{NO}_{\mathrm{x}}$ gases, although the former is more dominant than the latter (Wasmus et al., 1994; Kim et al., 2006). According to Kim et al. (2005), the ammonia was oxidized mainly to nitrogen gas through a direct electrolytic reaction in the basic solution, while ammonia could be partly decomposed to nitrogen by the hydroxyl radicals in the neutral and acid solution; besides, the ammonium ion could be oxidized to $\mathrm{NO}_{\mathrm{x}}$ and nitrogen by electrochemically generated hypochlorite plus hydroxyl radicals in the neutral condition. This explanation is also appropriate for the finding of $\mathrm{NO}_{\mathrm{x}}$ production from the electrochemical oxidation of ammonia in swine wastewater in this study. However, the evolution of oxygen on anode and that of hydrogen on cathode leading to an effect of ammonia stripping might also influence the rate of $\mathrm{NO}_{\mathrm{x}}$ release from wastewater into the air.

\section{Variations of Nitrite, Nitrate, and COD Concentrations over Time in Wastewater}

The reactions on both anode and cathode might influence the production and decomposition of ammonia, nitrite, nitrate, and COD, which then resulted in the variations of $\mathrm{NH}_{3}$ and $\mathrm{NO}_{\mathrm{x}}$ concentration over time in the air. Fig. 5(a) shows the variations of nitrite and nitrate concentrations over time in wastewater. For comparison, the data of $\mathrm{NH}_{3}-\mathrm{N}$ taken from Fig. 4(a) is also presented in Fig. 5(a). the concentration of $\mathrm{NH}_{3}-\mathrm{N}$ decreased over time from 661 to $\mathrm{ND}$, that of $\mathrm{NO}_{2}{ }^{-} \mathrm{N}$ slightly increased initially and then decreased over time (0.14-2.36 mg L$\left.{ }^{-1}\right)$, and that of $\mathrm{NO}_{3}{ }^{-}-\mathrm{N}$ significantly increased with an increasing time (88.5-259 $\left.\mathrm{mg} \mathrm{L}^{-1}\right)$ during the electrolysis of swine wastewater.

As discussed in the previous section, the decrease in $\mathrm{NH}_{3}-\mathrm{N}$ concentration over time was chiefly resulted from the reactions of free (or un-ionized) ammonia $\left(\mathrm{NH}_{3}\right)$ or ionized one $\left(\mathrm{NH}_{4}^{+}\right)\left(\mathrm{pK}_{\mathrm{a}}\right.$ of $\mathrm{NH}_{4}^{+} \leftrightarrow \mathrm{NH}_{3}=\sim 9.24$ (Huang et al., 2008)) with electrochemically generated active chlorine, which led to the formation of $\mathrm{NO}_{3}{ }^{-}$or chloramines. Kapałka et al. (2010) concluded that the oxidation of ammonia at $\mathrm{pH}$ $<8$ was mostly mediated by electro-generated in situ active free chlorine to enhance ammonia oxidation using BDD in the presence of chloride, because the dominant ammonia species was $\mathrm{NH}_{4}{ }^{+}$based on the $\mathrm{pK}_{\mathrm{a}}=7.50$ for $\mathrm{HOCl} \rightarrow \mathrm{OCl}^{-}$ $+\mathrm{H}^{+}$(Pérez et al., 2012). Nevertheless, they also indicated that direct (non-mediated) electrochemical oxidation of ammonia on BDD electrode proceeded mainly at $\mathrm{pH}>8$ via $\mathrm{NH}_{3}$ oxidation.

$2 \mathrm{NH}_{3} \rightarrow \mathrm{N}_{2}+6 \mathrm{H}^{+}+6 \mathrm{e}^{-}$

In addition to $\mathrm{N}_{2}, \mathrm{NO}_{2}^{-}$and $\mathrm{NO}_{3}{ }^{-}$might also be produced on the anode via the further oxidation of $\mathrm{NH}_{2} \mathrm{OH}$ or $\mathrm{NO}$ formed from electrochemical oxidation of ammonia (Kim et al., 2005) or by dissolution of nitrogen oxides, e.g., Eq. (15) in the aqueous phase (Bunce and Bejan, 2011). 

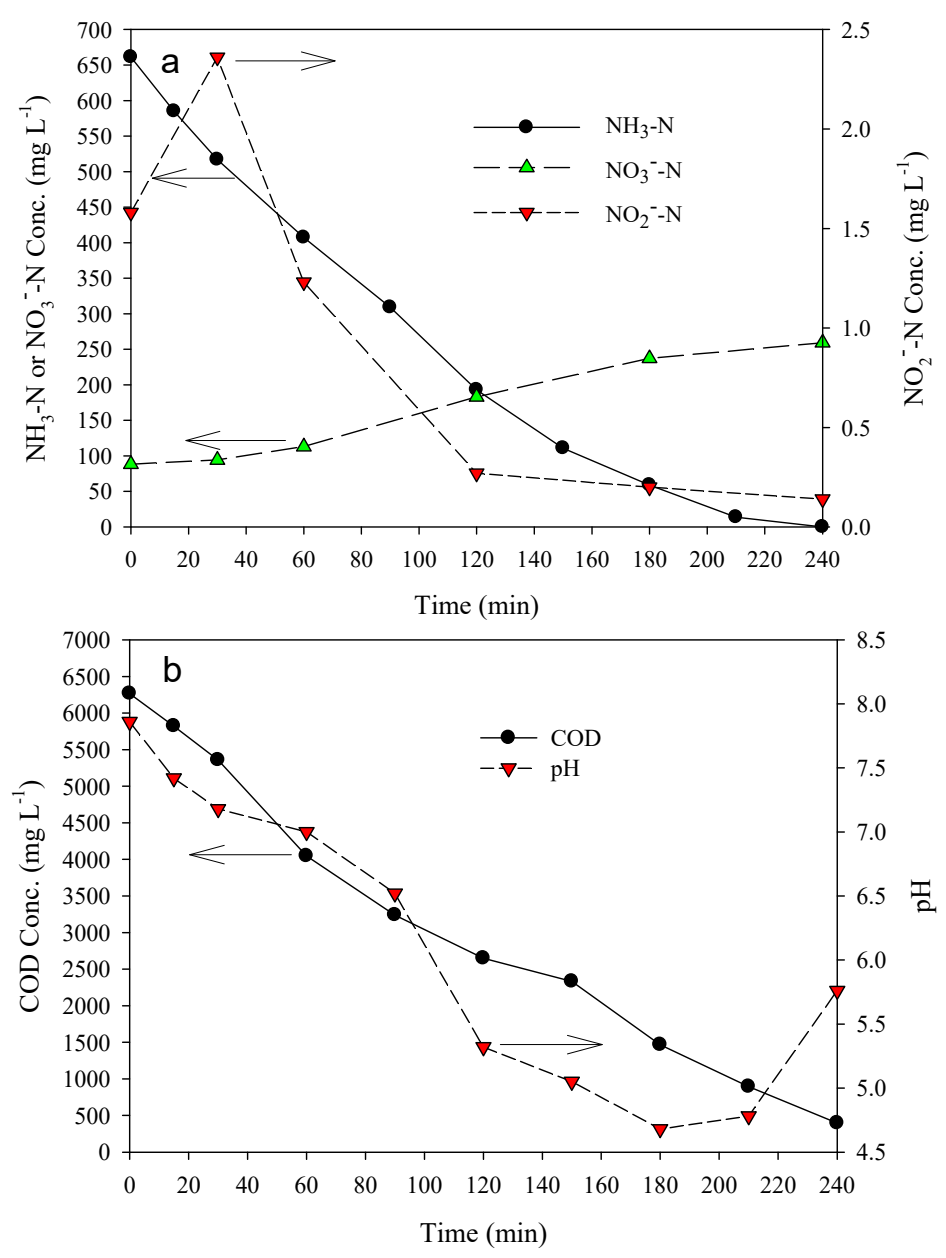

Fig. 5. Concentration variations in nitrogen compounds $\left(\mathrm{NH}_{3}-\mathrm{N}, \mathrm{NO}_{2}{ }^{-}-\mathrm{N}\right.$, and $\left.\mathrm{NO}_{3}{ }^{-} \mathrm{N}\right)$ (a) and $\mathrm{COD}$ and $\mathrm{pH}(\mathrm{b})$ over time in wastewater (Batch I, laboratory B).

$$
\begin{aligned}
& \mathrm{NH}_{3} \rightarrow \mathrm{NH}_{2} \mathrm{OH}_{\mathrm{ad}} \rightarrow \mathrm{NOH}_{\mathrm{ad}} \rightarrow \mathrm{NO} \rightarrow \mathrm{NO}_{2} \rightarrow \mathrm{NO}_{2}{ }^{-} \rightarrow \mathrm{NO}_{3}{ }^{-} \\
& \stackrel{\downarrow}{ } \\
& \mathrm{N}_{2} \text { or } \mathrm{N}_{2} \mathrm{O} \rightarrow \mathrm{N}_{2} \\
& 2 \mathrm{NO}_{2}+2 \mathrm{OH}^{-} \rightarrow \mathrm{NO}_{2}{ }^{-}+\mathrm{NO}_{3}{ }^{-}+\mathrm{H}_{2} \mathrm{O}
\end{aligned}
$$

In fact, these reactions are known to occur through more complicated steps. According to Bunce and Bejan (2011), the one-electron oxidation of water at the anode surface $\mathrm{MO}_{\mathrm{n}}$ initially yields an adsorbed hydroxyl radical $\mathrm{MO}_{\mathrm{n}} \mathrm{OH} \bullet$ (physisorbed active oxygen), which can be further oxidized to $\mathrm{MO}_{\mathrm{n}+1}$ (chemisorbed active oxygen) at noble metal oxides, such as $\mathrm{Ti} / \mathrm{IrO}_{2}, \mathrm{Ti} / \mathrm{RuO}_{2}$, and $\mathrm{PtO}_{\mathrm{x}}$. The $\mathrm{MO}_{\mathrm{n}+1}$ can initiate oxidation of a substrate by a two electron, one oxygen atom transfer mechanism. In the case of ammonia, this can form $\mathrm{H}_{3} \mathrm{~N}^{+}-\mathrm{O}^{-}$, tautomeric to $\mathrm{NH}_{2} \mathrm{OH}$; however, at anodes where $\mathrm{MO}_{\mathrm{n}} \mathrm{OH} \bullet$ cannot be oxidized further, such as $\mathrm{PbO}_{2}, \mathrm{Ti} / \mathrm{SnO}_{2}$, and BDD, the anode acts as a source of hydroxyl species in its reactions with external substrates (including ammonia). Nevertheless, $\mathrm{N}_{2}, \mathrm{~N}_{2} \mathrm{O}$, and $\mathrm{NO}_{2}$ may be formed from ammonia electrochemical oxidation on BDD in basic solution, and $\bullet \mathrm{OH}$ might react with $\mathrm{NH}_{3}$ to form $\mathrm{NH}_{2} \bullet$ ad (Eq. (16)), although the usual mechanism for oxidation of an extrinsic substrate at BDD is not yet clear (Bunce and Bejan, 2011). $\cdot \mathrm{OH}_{\mathrm{ad}}+\mathrm{NH}_{3} \rightarrow \cdot \mathrm{NH}_{2 \mathrm{ad}}+\mathrm{H}_{2} \mathrm{O}$

The $\mathrm{NH}_{4}{ }^{+}$in the neutral or acid solution can also be partly decomposed to nitrogen by $\bullet \mathrm{OH}$ (with a decomposition rate much lower than that in the basic condition), not by a direct electrode reaction (Kim et al., 2005).

The nitrite and nitrate could be reduced on cathode via the following reactions (Pérez et al., 2012), which should also participate in the variation in $\mathrm{NH}_{3}-\mathrm{N}, \mathrm{NO}_{2}{ }^{-}-\mathrm{N}$, and $\mathrm{NO}_{3}{ }^{-}-\mathrm{N}$ concentrations shown in Fig. 5(a).

$$
\begin{aligned}
& \mathrm{NO}_{3}^{-}+\mathrm{H}_{2} \mathrm{O}+2 \mathrm{e}^{-} \rightarrow \mathrm{NO}_{2}^{-}+2 \mathrm{OH}^{-} \\
& \mathrm{NO}_{3}{ }^{-}+6 \mathrm{H}_{2} \mathrm{O}+8 \mathrm{e}^{-} \rightarrow \mathrm{NH}_{3}+9 \mathrm{OH}^{-} \\
& \mathrm{NO}_{2}{ }^{-}+5 \mathrm{H}_{2} \mathrm{O}+6 \mathrm{e}^{-} \rightarrow \mathrm{NH}_{3}+7 \mathrm{OH}^{-} \\
& \mathrm{NO}_{2}^{-}+2 \mathrm{H}_{2} \mathrm{O}+3 \mathrm{e}^{-} \rightarrow 0.5 \mathrm{~N}_{2}+4 \mathrm{OH}^{-}
\end{aligned}
$$

The small nitrite concentration detected in our experiments was related to its almost instantaneous oxidation by $\mathrm{OCl}^{-}$in the presence of chloride during electrolysis (Pérez et al., 2012).

On the other hand, the concentration of COD decreased from 6266 to $397 \mathrm{mg} \mathrm{L}^{-1}$ over time in wastewater electrolysis 
(Fig. 5(b)) (pseudo first order rate constant of COD removal $\mathrm{k}_{\mathrm{COD}}=1.21 \times 10^{-4} \mathrm{~s}^{-1}$ in Table 1$)$. The electro-generated $\cdot \mathrm{OH}$ was principally responsible for the degradation and mineralization of COD (Li and Liu, 2009; Sirés et al., 2014; Radjenovic et al., 2015; Moreira et al., 2017). Moreover, the solution $\mathrm{pH}$ also decreased from 7.86 to 4.68 with time at $\mathrm{t}$ $\leq 180 \mathrm{~min}$ but it began to rise for the electrolysis after 180 min (Fig. 5(b)). The reactions 4-9 and 13-17 may cause the variation of $\mathrm{pH}$ in solution; furthermore, the electrochemical reactions for the evolution of oxygen on anode and that of hydrogen on cathode also involve in the $\mathrm{pH}$ change in solution. It was reported that the electrochemical production of $\bullet \mathrm{OH}$ were not favored in solution at $\mathrm{pH}>9$ [25]. $\mathrm{Cl}^{-}$may react with $\cdot \mathrm{OH}$ to generate $\mathrm{OCl}^{-}$, which can be further oxidized by $\cdot \mathrm{OH}$ to from $\mathrm{ClO}_{2}^{-}, \mathrm{ClO}_{3}^{-}$, and $\mathrm{ClO}_{4}^{-}$stepwise (Kapałka et al., 2010).

\section{Effect of Anode Material on $\mathrm{NH}_{3}$ and Nitrogen Oxides Concentration Variations in the Air}

Fig. 6(a) shows the increase in air $\mathrm{NH}_{3}$ concentration over time for the non-electrolyzed swine wastewater with an initial $\mathrm{NH}_{3}-\mathrm{N}$ concentration of $107 \mathrm{mg} \mathrm{L}^{-1}$, similar to the trend depicted in Fig. 4(a). However, the air $\mathrm{NH}_{3}$ concentration was greater in Fig. 4(a) than in Fig. 6(a), because the initial $\mathrm{NH}_{3}-\mathrm{N}$ concentration in wastewater was higher for the former than for the latter. The electrolysis of swine wastewater
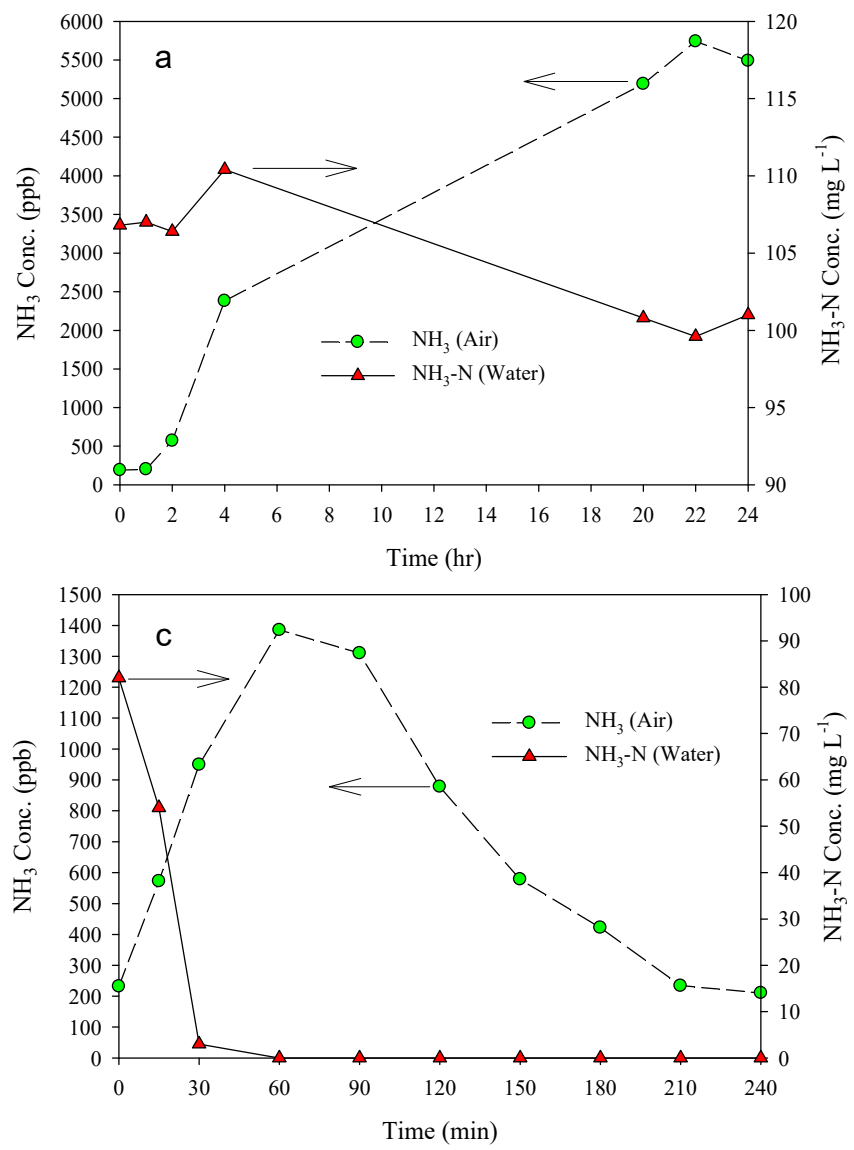

(initial $\mathrm{NH}_{3}-\mathrm{N}$ concentration $=98.2 \mathrm{mg} \mathrm{L}^{-1}$ ) using a $\mathrm{Ti} / \mathrm{PbO}_{2}$ anode exhibited an increase in air $\mathrm{NH}_{3}$ concentration at $\mathrm{t} \leq$ $60 \mathrm{~min}$ and then decreased at $\mathrm{t}>60 \mathrm{~min}$ (Fig. 6(b)), while the $\mathrm{NH}_{3}-\mathrm{N}$ concentration in wastewater decreased over time, also similar to the tendency shown in Fig. 4(a). This trend was also observed when replacing $\mathrm{Ti} / \mathrm{PbO}_{2}$ with BDD-I as the anode for the electrolysis of wine wastewater with an initial $\mathrm{NH}_{3}-\mathrm{N}$ concentration of $82.0 \mathrm{mg} \mathrm{L}^{-1}$ ) (Fig. 6(c)). However, the $\mathrm{NH}_{3}-\mathrm{N}$ concentration reached $\mathrm{ND}$ at $60 \mathrm{~min}$ for using the BDD-I anode, but the $\mathrm{NH}_{3}-\mathrm{N}$ concentration decreased smaller after $60 \mathrm{~min}$ and was only close to $10 \mathrm{mg} \mathrm{L}^{-1}$ for using the $\mathrm{Ti} / \mathrm{PbO}_{2}$ one. The removal rate of $\mathrm{NH}_{3}-\mathrm{N}$ was faster using the BDD-I than using the Ti $/ \mathrm{PbO}_{2}\left(\mathrm{k}_{\mathrm{NH}-\mathrm{N}}=4.83\right.$ $\times 10^{-4}$ and $4.63 \times 10^{-4} \mathrm{~s}^{-1}$, respectively) (Table 1 ); hence, the increase in air $\mathrm{NH}_{3}$ concentration was faster when using the BDD-I.

More anodes were tested to further explore the variations of air $\mathrm{NH}_{3}$ and nitrogen oxides concentrations during the electrolysis of swine wastewater. When using BDD-I as the anode, the air $\mathrm{NH}_{3}$ concentration increased with increase in electrolysis time, reached a maximum $(4450 \mathrm{ppb})$ at $60 \mathrm{~min}$, and then decreased over time (Fig. 7(a)). It was noticed that the air $\mathrm{NH}_{3}$ concentrations for using different anodes in wastewater electrolysis followed the order BDD-I $(\mathrm{Nb} / \mathrm{BDD})>>$ graphite/BDD $>$ graphite $>$ graphite $/ \mathrm{PbO}_{2} \approx$ $\mathrm{Ti} / \mathrm{PbO}_{2}$ (Fig. 7(a)). Therefore, using BDD anodes resulted

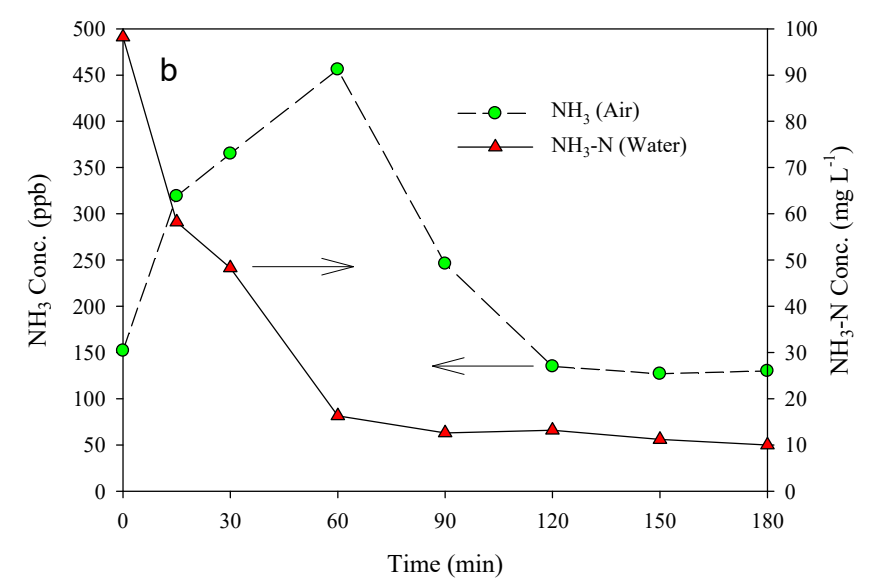

Fig. 6. Air $\mathrm{NH}_{3}$ and wastewater $\mathrm{NH}_{3}-\mathrm{N}$ concentration variations over time for the (a) wastewater without and (b) with electrolysis on $\mathrm{Ti} / \mathrm{PbO}_{2}$ (Batch II-01), and (c) BDD-I (Batch II-02) (laboratory A). 

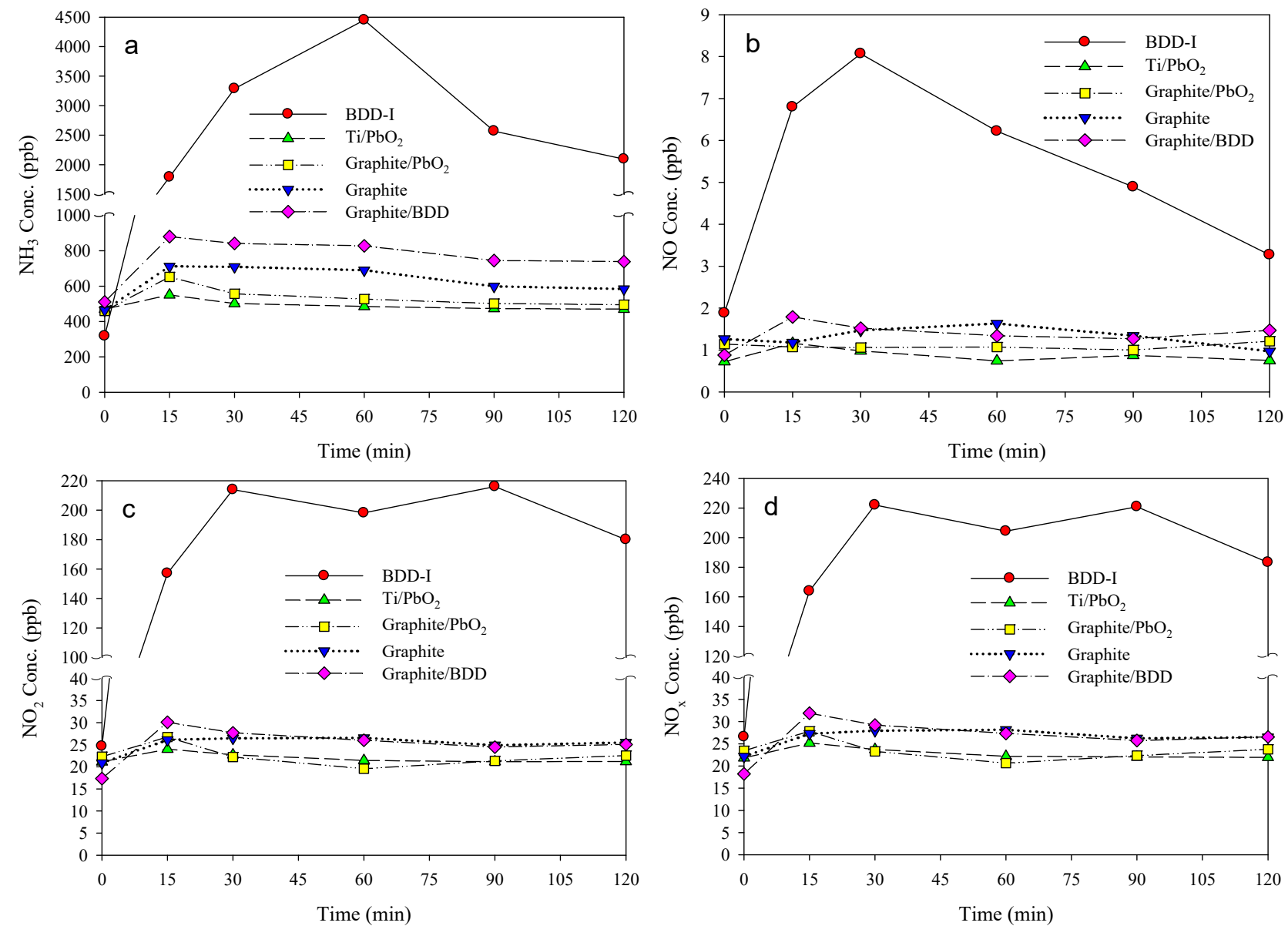

Fig. 7. Concentration variations in (a) $\mathrm{NH}_{3}$, (b) $\mathrm{NO}$, (c) $\mathrm{NO}_{2}$, and (d) $\mathrm{NO}_{\mathrm{x}}$ over time in the air (Batch II-1 to Batch II-5, laboratory A).

in more release of $\mathrm{NH}_{3}$ from wastewater into the air than using $\mathrm{PbO}_{2}$ or graphite, regardless of the difference in electrode substrate material. Similarly, the BDD-I anode still exhibited a significantly greater release of NO $($ maximum $=8.1 \mathrm{ppb})$ from wastewater into the air than the other tested anodes (Fig. 7(b)). However, the air $\mathrm{NH}_{3}$ concentrations for using graphite/BDD and graphite anodes were similar, and this tendency was also true for using graphite $/ \mathrm{PbO}_{2} \approx \mathrm{Ti} / \mathrm{PbO}_{2}$ ones. Like the trend of $\mathrm{NO}$ release from wastewater into the air, the air $\mathrm{NO}_{2}$ concentrations for using these anodes were in the order BDD-I $(\mathrm{Nb} / \mathrm{BDD})$ (maximum $=216 \mathrm{ppb}$ ) $>>$ graphite/BDD $\approx$ graphite $>$ graphite $/ \mathrm{PbO}_{2} \approx \mathrm{Ti} / \mathrm{PbO}_{2}$ (Fig. 7(c)). Consequently, this trend was also true for the air $\mathrm{NO}_{\mathrm{x}}$ concentrations (BDD-I, maximum $=222 \mathrm{ppb}$ ) when using these anodes. The significant deviation in air $\mathrm{NO}_{\mathrm{x}}$ concentration resulted from using BDD-I (Nb/BDD) and graphite/BDD is probably attributed to the BDD crystalline structure was significantly better for the former than for the latter, and the graphite/BDD should significantly had more graphite structure than the BDD-I. Further study on electrode surface analysis is necessary to verify this point. Accordingly, $\mathrm{NO}_{\mathrm{x}}$ formation was more favorable on BDD than on $\mathrm{PbO}_{2}$ or graphite. More study is necessary to explore the reaction mechanisms related to this issue (see more discussion in the next section).

\section{Effect of Anode Material on $\mathrm{NH}_{3}-\mathrm{N}, \mathrm{NO}_{2}^{-}-\mathrm{N}, \mathrm{NO}_{3}^{-}-\mathrm{N}$, and COD Concentration Variations in the Wastewater}

The performance of $\mathrm{NH}_{3}-\mathrm{N}$ degradation in wastewater for using the five tested anodes was in the order graphite $/ \mathrm{PbO}_{2}$ $\approx \mathrm{Ti} / \mathrm{PbO}_{2}>$ BDD-I $>>$ graphite/BDD $>$ graphite (Fig. 8(a)), consistent with their pseudo first order rate constants of $\mathrm{NH}_{3}-\mathrm{N}$ removal $\left(\mathrm{k}_{\mathrm{NH} 3-\mathrm{N}}=2.98 \times 10^{-4}-6.35 \times 10^{-4} \mathrm{~s}^{-1}\right)($ Table 1$)$. This result is similar to another study which used swine wastewater with comparable $\mathrm{NH}_{3}-\mathrm{N}$ and higher COD concentrations (Huang et al., 2019). The better removal rate of $\mathrm{NH}_{3}-\mathrm{N}$ on $\mathrm{PbO}_{2}$ than on BDD and graphite in wastewater was associated with the inherently different nature in electrode material and the mechanisms for ammonia removal. The difference in initial $\mathrm{NH}_{3}-\mathrm{N}$ concentration $\left(76.3-90.0 \mathrm{mg} \mathrm{L}^{-1}\right.$ ) was small (Table 1), so its influence on the $\mathrm{NH}_{3}-\mathrm{N}$ removal should be minor in comparison to that of anode material.

As discussed earlier, the dominant ammonia species is $\mathrm{NH}_{4}{ }^{+}$in neutral or acidic aqueous solution, which is not favored for the direct (non-mediated) oxidation of ammonia on anode (Pérez et al., 2012), while $\mathrm{NH}_{3}$ can be directly oxidized on BDD in basic solution (Kapałka et al., 2010), and both $\mathrm{NH}_{4}{ }^{+}$and $\mathrm{NH}_{3}$ can be oxidized by $\cdot \mathrm{OH}$ (Kim et al., 2005; Bunce and Bejan, 2011). The oxidation rate of ammonia was also slow by the $\cdot \mathrm{OH}$ generated from using $\mathrm{H}_{2} \mathrm{O}_{2}$ plus UV irradiation (Huang et al., 2008). However, for the swine 

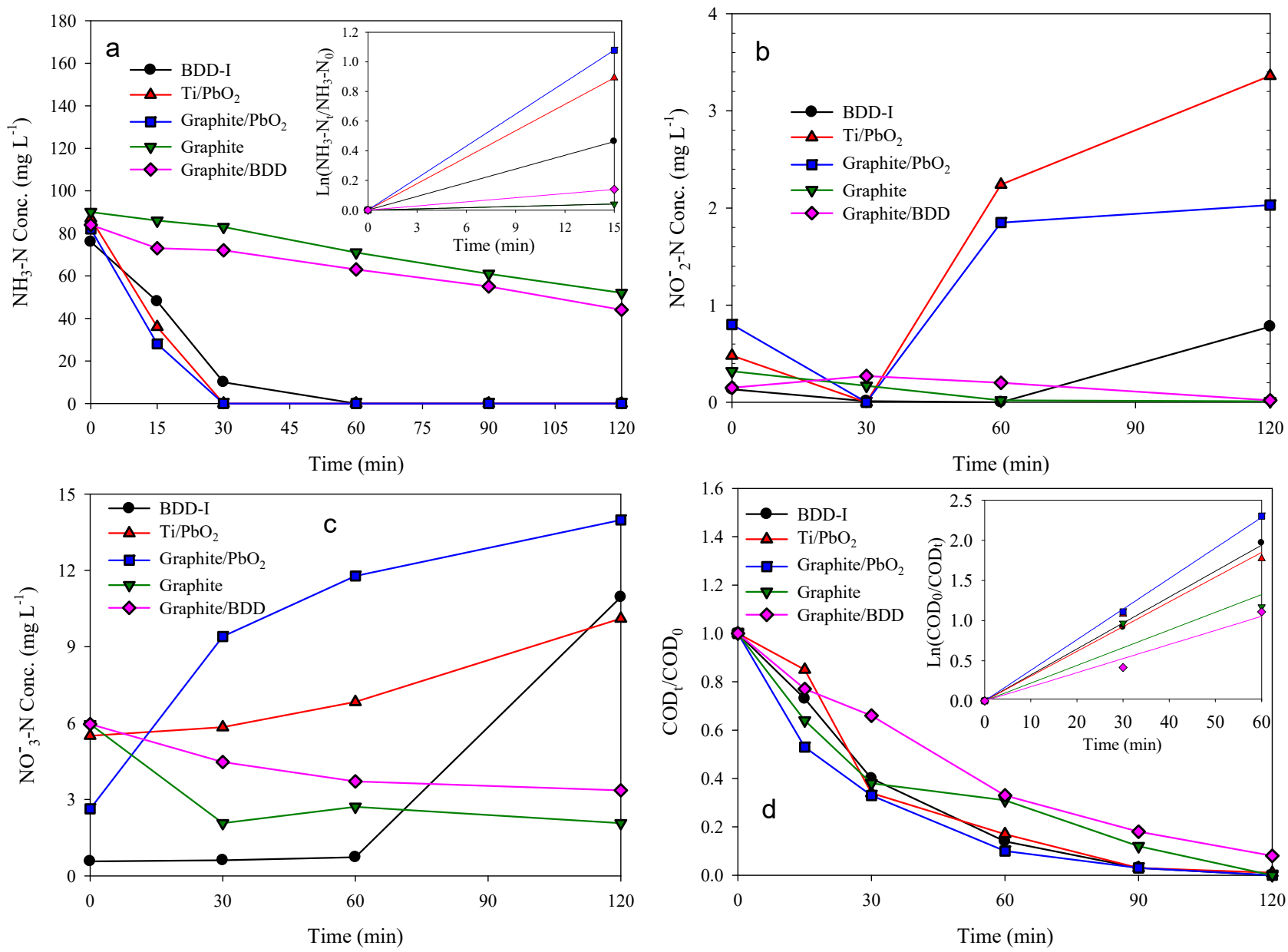

Fig. 8. Concentration variations in (a) $\mathrm{NH}_{3}-\mathrm{N}$, (b) $\mathrm{NO}_{2}{ }^{-}-\mathrm{N}$, (c) $\mathrm{NO}_{3}{ }^{-}-\mathrm{N}$, and (d) $\mathrm{COD}_{t} / \mathrm{COD}_{0}$ over time in wastewater (Batch II-1 to Batch II-5, laboratory A).

wastewater with the addition of $0.05 \mathrm{M} \mathrm{NaCl}$ in this study, the electro-generated active chlorine was more useful for mediated oxidation of ammonia than electro-produced $\cdot \mathrm{OH}$ (Kapałka et al., 2010; Pérez et al., 2012). On the other hand, the BDD or graphite anode exhibited less formation of nitrite (Fig. 8(b)) or nitrate (Fig. 8(c)) than the $\mathrm{PbO}_{2}$ one during the electrolysis of wastewater, also supporting that the electrogenerated active chlorine dominated for the ammonia removal in wastewater, although the Ti cathode was also responsible for the variations of nitrite and nitrate concentrations.

Fig. 8(d) shows that the graphite/BDD and graphite anodes exhibited worse performance in COD removal $\left(\mathrm{k}_{\mathrm{COD}}=4.50\right.$ $\left.\times 10^{-5}-1.55 \times 10^{-4} \mathrm{~s}^{-1}\right)$ than the other tested anodes $\left(\mathrm{k}_{\mathrm{COD}}=\right.$ $5.13 \times 10^{-5}-1.19 \times 10^{-3} \mathrm{~s}^{-1}$ ) (Table 1). This phenomenon is associated with the fact that the performance in electrochemical production of $\cdot \mathrm{OH}$ in water solution is better on non-active electrodes (e.g., $\mathrm{BDD}$ and $\mathrm{PbO}_{2}$ ) than on active electrodes (e.g., graphite and $\mathrm{Pt}$ ); moreover, the electro-generated $\cdot \mathrm{OH}$ is powerful for the degradation and mineralization of organic pollutants in solution (Comninellis, 1994; Sirés et al., 2014; Radjenovic et al., 2015; Moreira et al., 2017). According to Table 1, the initial COD concentration also affected the COD removal in wastewater. For example, the initial COD concentration in Batch I wastewater $\left(6266 \mathrm{mg} \mathrm{L}^{-1}\right)$ was significantly higher than that in Batch II-1 $\left(542 \mathrm{mg} \mathrm{L}^{-1}\right)$, so the former had a smaller $\mathrm{k}_{\mathrm{COD}}\left(1.21 \times 10^{-4} \mathrm{~s}^{-1}\right)$ than the latter $\left(5.13 \times 10^{-4} \mathrm{~s}^{-1}\right)$ when using the same BDD-I anode. In addition to anode material, the initial concentration of COD or $\mathrm{NH}_{3}-\mathrm{N}$ also influenced its specific energy consumption in electrolytic removal ( $E_{S P-C}$ and $E_{S P-N}$, respectively). For comparison and consistency, the $\mathrm{NH}_{3}-\mathrm{N}$ and COD reached ND at 0.5 (Fig. 8(a)) and 2 hrs (Fig. 8(d)), respectively, so the data of 0.5-hr ESP-N and 2-hr ESP-C are provided in Table 1. The ESP-C $\left(0.052-0.853 \mathrm{kWh} \mathrm{g-COD}{ }^{-1}\right)$ or E EP-N $(0.316-$

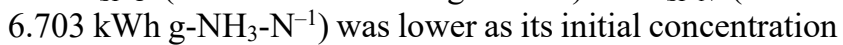
was higher. Therefore, the $\mathrm{E}_{\mathrm{SP}-\mathrm{C}}\left(0.052 \mathrm{kWh} \mathrm{g-COD}{ }^{-1}\right)$ and

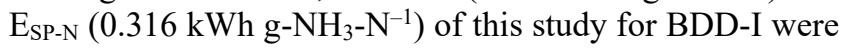

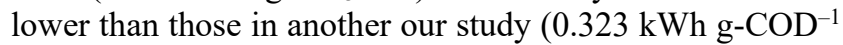

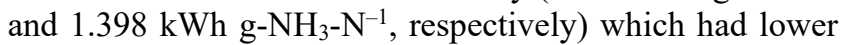
initial COD and $\mathrm{NH}_{3}-\mathrm{N}$ concentrations (1025 and $86 \mathrm{mg} \mathrm{L}^{-1}$ ), respectively (Huang et al., 2019). According to mass balance and using $1 \mathrm{~L}(10 \mathrm{~cm} \times 10 \mathrm{~cm} \times 10 \mathrm{~cm})$ for the space volume above the wastewater, the total nitrogen mass (the mass of $\mathrm{NH}_{3}-\mathrm{N}$ and $\mathrm{NO}_{\mathrm{x}}-\mathrm{N}$ in air plus that of $\mathrm{NH}_{3}-\mathrm{N}, \mathrm{NO}_{2}{ }^{-}-\mathrm{N}$, and $\mathrm{NO}_{3}{ }^{-}-\mathrm{N}$ in wastewater) at $0-\mathrm{hr}$ deducts that at $2-\mathrm{hr}$ is denoted as $\Delta \mathrm{N}_{\mathrm{T}}$ and the data of $\Delta \mathrm{N}_{\mathrm{T}}$ for different runs are also given in Table 1. The $\Delta \mathrm{N}_{\mathrm{T}}$ value of Batch I wastewater was $89.8 \mathrm{mg}$, significantly greater those of Batch II wastewater 
(9.97-17.4 mg), because the former had significantly higher ammonia concentration than the latter. The $\Delta \mathrm{N}_{\mathrm{T}}$ should be present as the other forms of nitrogen compounds (e.g., $\mathrm{N}_{2}$ and $\mathrm{N}_{2} \mathrm{O}$ ), and the change in organic nitrogen concentration in the wastewater should also involve in the change of $\Delta \mathrm{N}_{\mathrm{T}}$.

\section{CONCLUSIONS}

In this study, the $\mathrm{NH}_{3}$ concentration in the air right above the swine wastewater without electrolysis was found to increase over time and this increase of air $\mathrm{NH}_{3}$ concentration was greater when the wastewater $\mathrm{NH}_{3}-\mathrm{N}$ concentration was higher. During the electrolysis of this swine wastewater using each of five tested anodes, the air $\mathrm{NH}_{3}$ concentrations, increasing to a maximum and then decreasing over time, were smaller than those without electrolysis, mainly because the decrease in driving force for ammonia volatilization resulted from the decrease of wastewater $\mathrm{NH}_{3}-\mathrm{N}$ concentration over time. The NO concentration in the air was greater for the wastewater without electrolysis than for that with electrolysis but an opposite tendency was observed for $\mathrm{NO}_{2}$ in the air, while their corresponding $\mathrm{NO}_{\mathrm{x}}$ concentrations were similar at most of sampling intervals.

Both anode material and initial pollutant concentration influenced the release of $\mathrm{NH}_{3}$ and nitrogen oxides from wastewater into the air and the variations in $\mathrm{NH}_{3}-\mathrm{N}, \mathrm{NO}_{2}{ }_{-}^{-} \mathrm{N}$, $\mathrm{NO}_{3}{ }^{-} \mathrm{N}$, and $\mathrm{COD}$ concentrations in the wastewater. The air $\mathrm{NH}_{3}$ concentrations for using different anodes in wastewater electrolysis followed the order BDD-I (Nb/BDD) $>>$ graphite/ BDD $>$ graphite $>$ graphite $/ \mathrm{PbO}_{2} \approx \mathrm{Ti} / \mathrm{PbO}_{2}$, while for air $\mathrm{NO}, \mathrm{NO}_{2}$, or $\mathrm{NO}_{\mathrm{x}}$ concentrations the order slightly shifted to: $\mathrm{Nb} / \mathrm{BDD}>$ graphite/BDD $\approx$ graphite $>$ graphite $/ \mathrm{PbO}_{2} \approx$ $\mathrm{Ti} / \mathrm{PbO}_{2}$. The graphite/BDD and graphite anodes exhibited worse performance in $\mathrm{NH}_{3}-\mathrm{N}\left(\mathrm{k}_{\mathrm{NH} 3-\mathrm{N}}=2.98 \times 10^{-4}-6.35 \times\right.$ $\left.10^{-4} \mathrm{~s}^{-1}\right)$ or COD electro-degradation $\left(\mathrm{k}_{\mathrm{COD}}=4.50 \times 10^{-5}\right.$ $1.19 \times 10^{-3} \mathrm{~s}^{-1}$ ) than the other tested ones, but they exhibited less formation of nitrite or nitrate than the $\mathrm{PbO}_{2}$ anodes. The specific energy consumption of $\mathrm{NH}_{3}-\mathrm{N}$ or $\mathrm{COD}$ was lower as its initial concentration was higher.

\section{ACKNOWLEDGEMENT}

The authors would like to thank the Ministry of Science and Technology, Taiwan for financially supporting this research under Grant No. MOST 106-2221-E-020-003MY3. We are also grateful for the financial assistance of Prosperity Sci-Tech Co., Ltd. under a project (10700245) financially supported by the Kaohsiung Environmental Protection Bureau.

\section{REFERENCES}

Arogo, J., Zhang, R.H., Riskowski, G.L., Christianson, L.L. and Day, D.L. (1999). Mass transfer coefficient of ammonia in liquid swine manure and aqueous solutions. J. Agric. Eng. Res. 73: 77-86.

Bunce, N.J. and Bejan, D. (2011). Mechanism of electrochemical oxidation of ammonia. Electrochem. Acta 56: 8085-8093.
Cai, K., Li, S., Zheng, F., Yu, C., Zhang, X., Liu, Y. and Li, Y. (2018). Spatio-temporal variations in $\mathrm{NO}_{2}$ and $\mathrm{PM}_{2.5}$ over the central plains economic region of China during 2005-2015 based on satellite observations. Aerosol Air Qual. Res. 18: 1221-1235.

Chauret, C., Smith, C. and Baribeau, H. (2008). Inactivation of Nitrosomonas europaea and pathogenic Escherichia coli by chlorine and monochloramine. J. Water Health 6 : 315-322.

Chen, T.S., Huang, K.L. and Pan, Y.C. (2012). Electrochemical versus Ce(IV)-mediated electrochemical oxidation (MEO) degradation of acetaminophen in aqueous solutions. Int. J. Electrochem. Sci. 7: 11191-11205.

Cheng, N., Li, Y., Sun, F., Chen, C., Wang, B., Li, Q., Wei, P. and Cheng, B. (2018). Ground-Level $\mathrm{NO}_{2}$ in urban Beijing: trends, distribution, and effects of emission reduction measures. Aerosol Air Qual. Res. 18: 343-356.

Comninellis, Ch. (1994). Electrocatalysis in the electrochemical conversion/combustion of organic pollutants for waste water treatment. Electrochim. Acta 39: 1857-1862.

Deblitz, C., Verhaagh, M. and Rohlmann, C. (2018). Pig report 2018. Thünen Institute of Farm Economics, Federal Research Institute for Rural Areas, Forestry and Fisheries, Germany.

Ding, W., Cheng, S., Yu, L. and Huang, H. (2017). Effective swine wastewater treatment by combining microbial fuel cells with flocculation. Chemosphere 182: 567-573.

European Environment Agency (EEA) (2019). Ammonia emissions from agriculture continue to pose problems for Europe. https://www.eea.europa.eu/highlights/ammoniaemissions-from-agriculture-continue. Last Access: 26 September 2019.

Guthrie, S., Giles, S., Dunkerley, F., Tabaqchali, H., Harshfield, A., Ioppolo, B. and Manville, C. (2018). The impact of ammonia emissions from agriculture on biodiversity. The Royal Society, UK.

Huang, K.L., Wei, K.W., Chen, M.H. and Ma, C.Y. (2018). Removal of organic and ammonium nitrogen pollutants in swine wastewater using electrochemical advanced oxidation. Int. J. Electrochem. Sci. 13: 11418-11431.

Huang, K.L., Liu, C.C., Ma, C.Y. and Chen, T.T. (2019). Effects of operating parameters on electrochemical treatment of swine wastewater. Int. J. Electrochem. Sci., in Press.

Huang, L., Li, L., Dong, W., Liu, Y. and Hou, H. (2008). Removal of ammonia by $\mathrm{OH}$ radical in aqueous phase. Environ. Sci. Technol. 42: 8070-8075.

Kapałka, A., Joss, L., Anglada, A., Comninellis, Ch. and Udert, K.M. (2010). Direct and mediated electrochemical oxidation of ammonia on boron-doped diamond electrode. Electrochem. Commun. 12: 1714-1717.

Kim, K.W., Kim, Y.J., Kim, I.T., Park, G.I. and Lee, E.H. (2005). The electrolytic decomposition mechanism of ammonia to nitrogen at an $\mathrm{IrO}_{2}$ anode. Electrochem. Acta 50: 4356-4364.

Kim, K.W., Kim, Y.J., Kim, I.T., Park, G.I. and Lee, E.H. (2006). Electrochemical conversion characteristics of ammonia to nitrogen. Water Res. 40: 1431-1441. 
Kiros, F., Shakya, K.M. Rupakheti, M., Regmi, R.P., Maharjan, R., Byanju, R.M., Naja, M., Mahata, K., Kathayat, B. and Peltier, R.E. (2016). Variability of anthropogenic gases: Nitrogen oxides, sulfur dioxide, ozone and ammonia in Kathmandu Valley, Nepal. Aerosol Air Qual. Res. 16: 3088-3101.

Li, L. and Liu, L. (2009). Ammonia removal in electrochemical oxidation: Mechanism and pseudo-kinetics. J. Hazard. Mater. 161: 1010-1016.

Li, Y.C., Shu, M., Ho, S.S.H., Yu, J.Z., Yuan, Z.B., Liu, Z.F., Wang, X.X. and Zhao, X.Q. (2018). Effects of chemical composition of $\mathrm{PM}_{2.5}$ on visibility in a semirural city of Sichuan Basin. Aerosol Air Qual. Res. 18: 957-968.

Martínez-Huitle, C.A. and Ferro, S. (2006). Electrochemical oxidation of organic pollutants for the wastewater treatment: Direct and indirect processes. Chem. Soc. Rev. 35:1324-1340.

Montes, N., Otero, M., Coimbra, R.N., Méndez, R. and Martín-Villacorta, J. (2015). Removal of tetracyclines from swine manure at full-scale activated sludge treatment plants. Environ. Technol. 36: 1966-1973.

Moreira, F.C., Boaventura, R.A.R., Brillas, E. and Vilar, V.J.P. (2017). Electrochemical advanced oxidation processes: A review on their application to synthetic and real wastewaters. Appl. Catal., B 202: 217-261.

Osada, T., Shiraishi,M. Hasegawa, T. and Kawahara, H. (2017). Methane, nitrous oxide and ammonia generation in full-scale swine wastewater purification facilities. Front. Environ. Sci. Eng. 11: 10.

Pérez, G., Ibáñez, G.R., Urtiaga, A.M. and Ortiz, I. (2012). Kinetic study of the simultaneous electrochemical removal of aqueous nitrogen compounds using BDD electrodes. Chem. Eng. J. 197: 475-482.

Pinheiro, R.A., de Lima, C.M., Cardoso, L.R.D., TravaAiroldi, V.J. and Corat, E.J. (2016). Methods to grow porous diamond film doped with boron and nitrogen by deposition on carbon nanotubes. Diamond Relat. Mater. 65: 198-203.

Radjenovic, J. and Sedlak, D.L. (2015). Challenges and opportunities for electrochemical processes as nextgeneration technologies for the treatment of contaminated water. Environ. Sci. Technol. 49: 11292-11302.

Rahman, S. and Borhan, M.S. (2012). Typical odor mitigation technologies for swine production facilities A review. Civil Environ. Eng. 2: 117.

Sadanaga, Y., Takaji, R., Takami, A. and Bandow, H. (2017). Transboundary transport of nitrogen oxides from the Asian Continent to Fukue Island, Japan: Analyses of long-range transport of nitrogen compounds. Aerosol Air
Qual. Res. 17: 2981-2987.

Schmidt I. and Bock E. (1997). Anaerobic ammonia oxidation with nitrogen dioxide by Nitrosomonas eutropha. Arch. Microbiol. 167: 106-111.

Sirés, I., Brillas, E., Oturan, M.A., Rodrigo, M.A. and Panizza, M. (2014). Electrochemical advanced oxidation processes: Today and tomorrow. A review. Environ. Sci. Pollut. Res. 21: 8336-8367.

Song, X., Liu, R., Chen, L., Dong, B. and Kawagishi, T. (2017). Advantages of intermittently aerated SBR over conventional SBR on nitrogen removal for the treatment of digested piggery wastewater. Front. Environ. Sci. Eng. 11: 13.

Stuven, R. and Bock, E. (2001). Nitrification and denitrification as a source for $\mathrm{NO}$ and $\mathrm{NO}_{2}$ production in high-strength wastewater. Water Res. 35: 1905-1914.

Thurmon, F.M. and Ottenstein, B. (1952). Studies on the chemistry of human perspiration with especial reference to its lactic acid content. J. Invest. Dermatol. 18: 333339.

Ubeda, Y., Lopez-Jimenez, P.A., Nicolas, J. and Calvet, S. (2013). Strategies to control odours in livestock facilities: A critical review. Span. J. Agric. Res. 11: 1004-1015.

United States Environmental Protection Agency (U.S. EPA) (2013). Literature review of contaminants in livestock and poultry manure and implications for water quality. EPA 820-R-13-002.

Viguria, M., López, D.M., Arriaga, H. and Merino, P. (2015). Ammonia and greenhouse gases emission from on-farm stored pig slurry. Water Air Soil Pollut. 226: 285.

Wasmus, S., Vasini, E.J., Krausa, M., Mishima, H.T. and Vielstich, W. (1994). DEMS-cyclic voltammetry investigation of the electrochemistry of nitrogen compounds in $0.5 \mathrm{M}$ potassium hydroxide. Electrochim. Acta 39: 2331 .

Wright, L.P., Zhang, L., Cheng, I., Aherne, J. and Wentworth, G.R. (2018). Impacts and effects indicators of atmospheric deposition of major pollutants to various ecosystems - A review. Aerosol Air Qual. Res. 18: 19531992.

Yano, T., Tryk, D., Hashimoto, K. and Fujishima, A. (1998). Electrochemical behavior of highly conductive borondoped diamond electrodes for oxygen reduction in alkaline solution. J. Electrochem. Soc. 145: 1870-1876.

Received for review, September 30, 2019 Revised, October 12, 2019 Accepted, October 16, 2019 